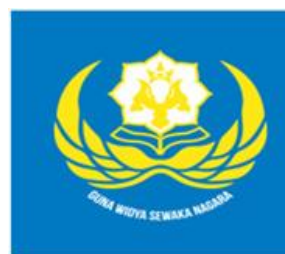

Linguistic Community Service Journal | Vol. 2, No. 2, 2021

P-ISSN: 2406-9019| E-ISSN: 2443-0668

Available online at

https://www.ejournal.warmadewa.ac.id/index.php/licosjournal

DOI: https://doi.org/10.22225/licosjournal.2.2.4051.49-59

\title{
MENINGKATKAN SANITASI MASYARAKAT DAN MEMAJUKAN UMKM DI DESA TEGAK KABUPATEN KLUNGKUNG DI MASA PANDEMI
}

\author{
Ni Ketut Sukiani*, Gusti Ayu Made Rai Suarniti \\ Universitas Warmadewa, Denpasar, Bali-Indonesia \\ *ketutsukiani@gmail.com, raisuarniti78@gmail.com
}

\begin{abstract}
Abstrak
Kegiatan ini bertujuan untuk meningkatkan tingkat kebersihan atau sanitasi masyarakat dan memajukan Usaha Mikro, Kecil dan Menengah (UMKM) di Desa Tegak, Kabupaten Klungkung di Masa Pandemi. Hal ini dilakukan dengan melaksanakan beberapa program. Kegiatan ini dapat dilaksanakan berkat kerja sama Universitas Warmadewa dengan masyarakat Desa Tegak. Penelitian ini ditulis dengan metode kualitatif, dan pengumpulan data dilakukan dengan metode observasi langsung dan wawancara. Kegiatan pengabdian ini dilaksanakan dengan membantu mempromosikan UMKM melalui platform media social, mengedukasi cara mencuci tangan yang benar, pembagian masker gratis, dan pemasangan poster edukasi pencegahan COVID-19, serta membantu kegiatan vaksinasi COVID-19, dan membantu kegiatan opnam purna laksana pembangunan fasilitas MCK dan penanaman pohon. Adapun program-program yang telah terlaksana baik di Desa Tegak, Kecamatan Klungkung, Kabupaten Klungkung antara lain program promosi Usaha Mikro, Kecil, dan Menegah (UMKM), program edukasi cara mencuci tangan yang benar, program pembagian masker gratis dan pemasangan poster edukasi pencegahan COVID-19, program membantu pelaksanaan vaksinasi COVID-19, membantu kegiatan posyandu, kegiatan penyerahan Bantuan Langsung Tunai (BLT) dana Desa Tegak Tahun Anggaran 2021 tahap V bulan Mei 2021, program survey pendataan penduduk SDGs desa tahun 2021, dan program peningkatan sanitasi dan peduli lingkungan.
\end{abstract}

Kata Kunci: Pandemi, Sanitasi UMKM

\begin{abstract}
This activity aims to improve the level of community hygiene or sanitation and promote Micro, Small and Medium Enterprises (MSMEs) in Tegak Village, Klungkung Regency during the Pandemic Period. This is done by implementing several programs. This activity can be carried out thanks to the collaboration between Warmadewa University and the people of Upright Village. This study was written with a qualitative method, and data collection was carried out by direct observation and interviews. This service activity is carried out by helping promote MSMEs through social media platforms, educating on how to wash hands properly, distributing free masks, and installing educational posters for COVID-19 prevention, as well as assisting with COVID-19 vaccination activities, and assisting after-care activities such as the construction of MCK facilities. and tree planting. The programs that have been implemented well in Tegak Village, Klungkung District, Klungkung Regency include the promotion program for Micro, Small, and Medium Enterprises (MSMEs), an educational program on how to wash hands properly, a program for distributing free masks and the installation of educational posters for COVID-19 prevention, a program to assist in the implementation of COVID-19 vaccination, assisting posyandu activities, handing over direct cash assistance (BLT) for Upright Village funds for the 2021 fiscal year 2021 phase V in May 2021, the village SDGs population data survey program in 2021, and programs to improve sanitation and care for the environment.
\end{abstract}

Keywords: Pandemic, Sanitation, MSME

\section{PENDAHULUAN}

Pandemi pada umumnya berdampak buruk bagi banyak hal di kehidupan. World Health Organization (WHO) dalam (Assri, 2020) mendefinisikan pandemi sebagai "epidemi yang terjadi di seluruh dunia, atau di wilayah yang sangat luas, melintasi batas internasional dan biasanya 
mempengaruhi sejumlah besar orang". Salah satu pandemi yang baru-baru ini muncul adalah COVID19. Dimulai pada 2019, virus ini menyebar melalui kontak langsung antar individu, termasuk juga orang-orang yang berdekatan tapi tidak bersentuhan langsung satu dengan yang lain. Hal ini dapat terjadi karena virus ini juga menyebar melalui butiran air tak kasat mata yang ada di udara. Butiran tersebut muncul dari hasil sistem pernapasan penderita COVID-19, misalnya bersin dan batuk. Karena inilah penting untuk menggunakan masker dan melakukan pencegahan contohnya social distancing dan mencuci tangan. Dengan cara-cara tersebut, antisipasi penyebaran virus COVID-19 juga dapat dilakukan dengan meningkatkan sanitasi lingkungan. Rudiyanto dalam (Floridiana, 2019) mengatakan bahwa sanitasi lingkungan penting untuk dijaga agar tidak terjadi kontaminasi. Kontaminasi dalam hal ini adalah virus COVID-19. Tingkat sanitasi berbanding terbalik dengan penularan wabah, yaitu semakin tinggi tingkat sanitasi lingkungan maka semakin rendah tingkat penularan COVID-19. Inilah pentingnya menjaga kebersihan dan meningkatkan sanitasi di masa pandemi. Selain itu, peningkatan sanitasi di Indonesia juga perlu dilakukan karena rendahnya kondisi sanitasi secara umum di negara ini. Adhi (2009) mengatakan bahwa kondisi sanitasi di Indonesia sudah kritis dan pencapaian target MDGs Indonesia kurang menunjukkan kemajuan yang berada di bawah capaian negara tetangga, terutama dalam hal sanitasi. Hal ini menggambarkan seberapa darurat Indonesia dalam hal sanitasi, dan menunjukkan pentingnya meningkatkan sanitasi lingkungan terutama di masa pandemi.

Selain mencegah penularan wabah melalui peningkatan sanitasi, ekonomi warga juga perlu ditingkatkan. Seperti yang diketahui, pandemi COVID-19 juga menghantam sektor ekonomi seluruh dunia. Terlebih lagi, Hanoatubun (2020) menyebutkan bahwa penyebaran virus Corona yang telah meluas ke berbagai belahan dunia membawa dampak pada perekonomian Indonesia, baik dari sisi perdagangan, investasi, dan pariwisata (2020: 147). Dari segi ekonomi, salah satu yang paling terkena dampak dari pandemi COVID-19 adalah pengusaha UMKM atau Usaha Mikro, Kecil, dan Menengah. Banyak pengusaha UMKM yang berkurang pendapatannya atau bahkan hingga gulung tikar akibat pandemi ini. Maka dari itu, penting bagi mereka untuk meningkatkan usaha mereka agar tetap bertahan, salah satu caranya adalah dengan promosi.

Desa Tegak merupakan salah satu dari banyak daerah yang terkena imbas pandemi. Desa tegak merupakan salah satu dari 53 desa yang ada di Kabupaten Klungkung. Desa Tegak memiliki potensi sumber daya manusia aktif yang cukup banyak, dan hal ini menjadi salah satu keunggulan di masa pandemi ini. Masyarakat Desa Tegak banyak yang memiliki profesi menjadi pengusaha UMKM, dan bahkan ada yang masih beroperasi dengan normal di masa pandemi meski dengan profit yang menurun. Dengan ditetapkannya protokol kesehatan dan era new normal, tidak sedikit warga Desa Tegak yang kurang memahami protokol kesehatan yang ditetapkan pemerintah. Contohnya seperti kurang taatnya penggunaan masker serta tidak menjaga jarak antar individu. Dapat dilihat pentingnya edukasi seputar pandemi COVID-19 untuk masyarakat Desa Tegak.

Universitas Warmadewa seiring dengan diadakannya program pengabdian masyarakat berupa KKN mengirimkan sejumlah mahasiswa ke berbagai daerah di Bali untuk membantu masyarakat daerah bersangkutan bangkit dari pandemi, salah satunya adalah Desa Tegak. Demi meningkatkan sanitasi dan memajukan UMKM Desa Tegak, mahasiswa KKN Warmadewa membawakan beberapa program, diantaranya program promosi UMKM dan edukasi dan kegiatan seputar sanitasi dan kebersihan. Selain itu, dilakukan juga beberapa program pendukung yang diharapkan mampu mencapai tujuan dari pengabdian masyarakat tersebut.

Berdasarkan deskripsi di atas, program meningkatkan sanitasi dan memajukan UMKM dibawakan oleh mahasiswa KKN Warmadewa kepada masyarakat Desa Tegak sebagai bagian dari kegiatan pengabdian masyarakat. Hal ini tidak mengurangi ketulusan dari pelaksanaan kegiatan tersebut.

\section{METODE PENELITIAN}

Penelitian ini membahas tentang meningkatkan sanitasi dan memajukan UMKM Desa Tegak di masa pandemi. Hal ini dilakukan melalui beberapa program yaitu program promosi UMKM, program edukasi cara mencuci tangan, pembagian masker gratis dan pemasangan poster seputar COVID-19, dan program sanitasi serta peduli lingkungan. Laporan ini dibuat dengan metode penelitian kualitatif. Menurut Bogdan dan Taylor dalam (Moleong, 2010) metodologi kualitatif merupakan prosedur penelitian yang menghasilkan data deskriptif berupa kata-kata tertulis atau lisan dari orang-orang dan perilaku yang bisa kita amati. Penelitian ini dilakukan dengan bantuan warga Desa Tegak sebagai 
sumber data. Data dikumpulkan melalui metode observasi langsung dan wawancara. Penelitian ini dilakukan dengan tujuan meningkatkan sanitasi dan memajukan UMKM masyarakat yang dilakukan dengan melaksanakan program-program yang terkait dengan sanitasi dan UMKM. Program-program tersebut antara lain program promosi UMKM, program edukasi cara mencuci tangan, pembagian masker gratis dan pemasangan poster seputar COVID-19, dan program sanitasi serta peduli lingkungan. Selain itu, dilaksanakan juga beberapa program tambahan seperti membantu kegiatan posyandu, membantu pembagian BLT, dan survey pendataan SDGs.

Program pertama yang diusung oleh mahasiswa KKN adalah program di bidang ekonomi yaitu program promosi Usaha Mikro, Kecil dan Menengah (UMKM). Program kerja ini dilaksanakan untuk membantu perekonomian masyarakat Desa Tegak agar mampu bertahan dan bangkit di masa pandemi ini. Dengan membantu mempromosikan UMKM melalui platform media sosial, diharapkan masyarakat pelaku UMKM dapat memanfaatkan platform ini sebagai media untuk mempromosikan produk dan usahanya dengan tujuan meningkatkan profit dari UMKM bersangkutan di tengah pandemi COVID-19.

Program kedua yang dibawakan oleh mahasiswa KKN adalah kegiatan sanitasi untuk pencegahan COVID-19, yang di dalamnya termasuk program edukasi cara mencuci tangan yang benar, pembagian masker gratis, dan pemasangan poster edukasi pencegahan COVID-19, serta membantu kegiatan vaksinasi COVID-19. Program kerja ini diajukan untuk membantu masyarakat di Desa Tegak agar mampu bertahan dan bangkit dari pandemi dengan mengetahui cara mencuci tangan yang benar, taat dengan protokol kesehatan, dan mengetahui informasi terkait virus COVID-19. Diharapkan agar masyarakat mampu mempertahankan dan meningkatkan tingkat kebersihan dan kesehatan di Desa Tegak selama pandemi berlangsung.

Program ketiga yang disusun oleh mahasiswa KKN Universitas Warmadewa berhubungan dengan sanitasi dan peduli lingkungan, yang dilaksanakan melalui program-program seperti membantu kegiatan opnam purna laksana pembangunan fasilitas MCK dan penanaman pohon. Diharapkan nantinya masyarakat dapat menjalankan new normal dengan bersih dan tetap menerapkan protokol kesehatan yang telah ditentukan sehingga Desa Tegak nantinya mampu melewati masa pandemi ini. Selain ketiga program utama di atas, dilaksanakan juga beberapa program pendukung yaitu kegiatan turut serta dalam pembagian BLT dan survey pendataan SDGs.

\section{HASIL DAN PEMBAHASAN \\ Program Promosi Usaha Mikro, Kecil, dan Menegah (UMKM)}

Program pertama yang dibawakan mahasiswa KKN Universitas Warmadewa adalah program peningkatan UMKM melalui promosi di sosial media. Mahasiswa KKN membantu mempromosikan usaha UMKM tersebut melalui platform sosial media untuk memperluas jaringan pelanggan tidak saja warga lokal namun dari luar desa melalui media sosial. Berikut merupakan evaluasi dan hasil dari UMKM yang turut serta dalam program ini:

UMKM pertama adalah usaha pengerajin emas dan perak milik Bapak I Wayan Suita.Bapak. I Wayan Suita sebagai pemilik memulai usahanya pada tahun 1990 dan mulai berkembang hingga saat ini. Permasalahan yang ditemui yaitu Selama masa pandemi sejak awal 2020, setahun lalu pesanan emas dan perak yang diterima bapak I Wayan Suita terus mengalami penurunan hingga 50 persen, dibandingkan saat sebelum pandemi Covid-19 melanda khususnya di Bali, yang berimbas pada pendapatan yang juga ikut mengalami penurunan. Seperti yang disebutkan sebelumnya,sebagai pemecahan masalah mahasiswa KKN membantu mempromosikan UMKM melalui media sosial. Harapan dari bapak I Wayan Suita selaku pemilik UMKM Pandemi Covid-19 segera berlalu dan dengan adanya mahasiswa KKN, bisa ikut membantu mempromosikan usahanya sehingga dapat meningkatkan pesanan emas dan perak. Dengan memperluas jaringan pelanggan tidak saja warga lokal, namun dari luar melalui media sosial, sehingga mampu kembali meningkatkan profit dari usahanya tersebut.

UMKM selanjutnya adalah usaha pandai besi pengerajin alat-alat perkakas milik Bapak I Wayan Suarna. Bapak I Wayan Suarna memulai usahanya sejak tahun 1973 dan masih eksis hingga saat ini. Usaha yang dimiliki bapak I Wayan Suarna ini berupa kerajinan pandai besi (alat-alat perkakas) dengan membuat pisau, blakas (pisau daging), sabit dan segala macam perabotan yang berbahan dari besi. Tidak banyak permasalahan yang dialami UMKM ini karena usaha kerajinan pandai besi milik bapak I Wayan Suarna sampai saat ini masih tergolong aman dan tidak berpengaruh 
signifikan dengan adanya pandemi Covid-19. Hanya saja penjualan beliau masih secara tradisional belum ada promosi produk ataupun pemasaran online barang yang digunakan oleh pemilik usaha. Oleh karena itu, mahasiswa KKN-PPM-Pandemi COVID-19 membantu mempromosikan UMKM melalui platform media sosial. Harapan Bapak I Wayan Suarna selaku pemilik UMKM agar pandemi segera berlalu dan dengan mahasiswa ikut membantu mempromosikan usahanya dapat meningkatkan orderan pandai besi miliknya juga dapat memperluas jaringan pelanggan sehingga mampu pula meningkatkan lagi profit dari usahanya tersebut.

Berikutnya adalah UMKM milik Bapak I Made Konten yang seorang pengerajin ingka.Bapak I Made Konten sebagai pemilik memulai usahanya pada tahun 2019 dan berkembang hingga saat ini. Usaha yang dimiliki bapak I Made Konten ini hasil kerajinan tradisional berupa ingka (anyaman dari lidi), sebagai alat pengganti piring. Ingka yang di produksi memiliki 2 (dua) ukuran besar dan kecil, dengan harga berbeda-beda menyesuaikan ukuran ingka tersebut. Pesanan hingga saat ini terbilang masih tetap lancar. Bahan baku pun ada dan banyak, namun pemilik sering kesulitan memenuhi pesanan pelanggan karena tenaga (SDM) untuk membuat ingka yang masih kurang. Mahasiswa KKNPPM-Pandemi Covid-19 memberikan solusi kepada pemilik agar bisa membentuk kelompok untuk ikut memproduksi ingka minimal sebanyak 10-15 orang agar bisa menerima lebih banyak pesanan lagi. Selain itu kedepannya untuk permodalan, pemerintah daerah dapat lebih mudah memberikan bantuan UMKM setelah terbentuk menjadi satu badan atau kelompok usaha. Mahasiswa juga turut serta membantu mempromosikan usaha ingka tersebut di platform media sosial sehingga dapat memperluas jaringan pelanggan dan otomatis meningkatkan profit dari usahanya. Harapan dari bapak I Made Konten selaku pemilik UMKM agar pandemi segera berlalu dan dengan mahasiswa ikut membantu mempromosikan usahanya dapat meningkatkan orderan anyaman ingka, dapat memperluas jaringan pelanggan sehingga mampu pula meningkatkan lagi profit dari usahanya tersebut.

UMKM selanjutnya merupakan usaha ternak babi. Bapak I Made Dwi Adnyana adalah sebagai pemilik memulai usahanya pada tahun 2015 silam dan masih eksis hingga saat ini. Usaha yang dimiliki bapak I Made Konten ini yaitu beternak dan jual beli babi. Selain itu limbah dari ternak babi yang beliau kelola dijadikan biogas. Permasalahan yang dialami oleh pemilik saat ini adalah harga bibit babi yang mahal dan sejak adanya Virus ASF pemilik mengalami kerugian yang cukup banyak. Selain itu pakan babi juga terus mengalami kenaikan harga. Mahasiswa KKN-PPM-Pandemi Covid19 membantu mempromosikan UMKM melalui platform media sosial. Pemilik berharap dengan bantuan promosi dari mahasiswa KKN dapat meningkatkan kembali profit dari usahanya dan pemilik dapat mudah memperoleh bibit dengan harga lebih murah. Dan berharap harga bibit bisa lebih stabil sehingga usahanya bisa berjalan lebih normal lagi.

Usaha peternakan ayam petelur milik Bapak I Ketut Sukasmawan merupakan UMKM yang berikutnya. Usaha ini dimulai pada tahun 2008 yang pada saat itu berawal dari ternak ayam boiler dan kemudian beralih ke ayam petelur dan berkembang hingga saat ini. Untuk penjualan telur ayam sendiri masih stabil, namun terkendala oleh keadaan kandang dimana sirkulasi udara yang kurang dengan kapasitas ayam petelur 7000 ekor ayam. Selain itu harga pakan ayam yang terus mengalami kenaikan berimbas pada laba yang didapatkan ikut mengalami penurunan. Mahasiswa KKN-PPMPandemi Covid-19 membantu mempromosikan UMKM melalui platform media sosial. Pemilik berharap dengan bantuan promosi dari mahasiswa KKN dapat meningkatkan kembali profit dari usahanya dan sukses. Dan ikut membantu agar harga pakan bisa lebih stabil lagi utamanya pada saat pandemi ini harga pakan terus mengalami lonjakan.

Serupa dengan Bapak I Ketut Sukasmawan, Bapak Wayan Nuarta juga merupakan seorang pengusaha di bidang peternakan telur. Wayan Nuarta telah memulai usaha telur ayam dan ternak ayam pada bulan Mei 2015 dengan jumlah awal ayam sebanyak 200 ekor. Dari awal didirikan peternakan ini telah 3 periode berganti ayam, penghasilan telur 1 hari sebanyak $10 \mathrm{kre}, 1$ periode ayam selama 2 tahun. Untuk penjualan 1 kre telur berkisar 40-45 tergantung ukuran telur. Dan telurtelur tersebut juga harus melewati penyortiran. Pakan ayam diambil dari kerja sama perusahaan dan kotoran ayam dapat dijual. Selama masa pandemi ini harga telur murah, tetapi harga pakan ayam yang meningkat. Dan pada saat ayam mati menyebabkan rugi dari produksi telur. Mahasiswa KKN-PPMPandemi Covid-19 turut membantu mempromosikan UMKM melalui platform media sosial. Pemilik berharap dengan bantuan promosi dari mahasiswa KKN dapat meningkatkan kembali profit dari usahanya dan membantu memperluas jaringan pelanggan di luar Desa Tegak dan juga bapak Artama berharap agar usahanya tetap produksi telur dan agar tetap bisa beli pakan. 
UMKM berikutnya adalah usaha pengerajin tenun ikat Bintang Timur. Bapak I Made Swabawa sebagai pemilik memulai usahanya pada tahun 1999 dan masih berkembang hingga saat ini. Usaha yang dimiliki bapak I Made Swabawa ini yaitu kerajinan dan penjualan tenun ikat (endek) tradisional. Di awal Pandemi Covid-19 produksi dan penjualan sempat mengalami penurunan, namun dapat terbantu dari program pemerintah daerah untuk penggunaan endek bagi masyarakat yang bekerja sehingga saat ini produksi dan penjualan tenun ikat berangsur-angsur membaik. Sistem karyawan tenun ada tiga jenis yaitu sistem borongan, harian dan juga bulanan. Karyawan yang dimiliki berjumlah 50 orang, dimana mereka terbagi menjadi 2, ada yang menenun di tempat usaha tersebut dan ada pula yang menenun di rumah karyawan itu sendiri. 1 orang karyawan dapat menyelesaikan tenun 32 kamen atau sekitar 70 meter selama 1 bulan. Harga tenun ikat sekitaran dari harga Rp. 200.000,- sampai Rp.1.000.000,-. Selama pandemi produksi dan penjualan menjadi menurun, namun saat ini dapat terbantu dari program pemerintah daerah untuk penggunaan endek bagi masyarakat yang bekerja, sehingga produksi dan penjualan tenun ikat berangsur-angsur mulai stabil. Mahasiswa KKN-PPM-Pandemi Covid-19 membantu mempromosikan UMKM melalui platform media sosial. Pemilik berharap dengan bantuan promosi dari mahasiswa KKN dapat meningkatkan kembali profit dari usahanya.

Selanjutnya, usaha produksi tempe D'Sentul CS merupakan UMKM milik Bapak I Komang Surata. Usaha ini dimulai pada tahun 2020 dimana usaha ini dirintis disaat pandemi. Usaha yang dimiliki Bapak I Komang Surata ini yaitu produksi dan penjualan tempe. Selama pandemi produksi dan penjualan menjadi menurun, yang biasanya sehari dapat menghabiskan bahan kedelai habis dalam $50 \mathrm{~kg} / 1$ sak kedelai kini hanya setengahnya. Selain itu harga kedelai yang mahal berkisar Rp. 500.000,-/sak juga menjadi penyebab turunnya penjualan tempe. Mahasiswa KKN-PPM-Pandemi Covid-19 turut membantu mempromosikan UMKM melalui platform media sosial. Pemilik berharap dengan bantuan promosi dari mahasiswa KKN dapat meningkatkan kembali profit dari usahanya.

UMKM berikutnya yaitu usaha Tenun Songket. Ibu Ni Wayan Rustini sebagai pemilik memulai usahanya pada tahun 1980 dimana usaha ini dirintis dari sejak pemilik masih remaja. Usaha yang dimiliki Ibu Ni Wayan Rustini ini yaitu pengerajin Tenun Songket tradisional, beliau membuka usaha sendiri dan bekerja sendiri. Satu kamen songket dikerjakan selama satu bulan (ukuran 2,5 meter). Dalam masa pandemi ini, orderan tenun songket sendiri masih stabil namun promosi produk usaha dan penjualannya masih bersifat manual. Mahasiswa KKN-PPM-Pandemi Covid-19 turut membantu mempromosikan UMKM melalui platform media sosial. Pemilik berharap dengan bantuan promosi dari mahasiswa KKN dapat meningkatkan kembali profit dari usahanya.

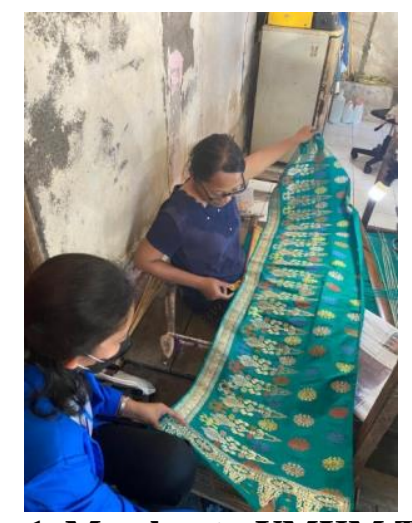

\section{Gambar 1. Membantu UMKM Tenun Songket}

Kopi Yas milik I Komang Gede Wiria Utama adalah UMKM berikutnya, usahanya dimulai pada tahun 2019 dimana usaha ini dirintis oleh ibu dari pemilik bernama ibu Kadek Yastini. Usaha yang dimiliki I Komang Gede Wiria Utama ini yaitu memproduksi dan penjualan kopi tradisional Bali asli robusta. Masalah yang dihadapi saat ini hanya jumlah penjualan yang menurun. Mahasiswa KKNPPM-Pandemi Covid-19 turut membantu mempromosikan UMKM melalui platform media sosial. Pemilik dengan bantuan promosi dari mahasiswa KKN dapat meningkatkan kembali profit dari usahanya dan membantu memperluas jaringan pelanggan di luar Desa Tegak.

UMKM berikutnya adalah milik Bapak Putu Agus Harimbawa, yaitu usaha produksi dupa yang 
bernama Dewi Wangi. Usaha ini telah dijalankannya dari tahun 2018. Dupa yang diproduksi juga ada berbagai macam. Untuk penjualan sendiri menurun $30 \%$ dari sebelum pandemi, selain itu bahan dupa mahal dan daya beli masyarakat juga menurun. Mahasiswa KKN-PPM-Pandemi Covid-19 turut membantu mempromosikan UMKM melalui platform media sosial. Pemilik berharap dengan bantuan promosi dari mahasiswa KKN dapat meningkatkan kembali profit dari usahanya dan membantu memperluas jaringan pelanggan di luar Desa Tegak

Usaha Kacang Kapri (PIN 2) adalah UMKM berikutnya. Produksi kacang kapri (PIN 2) memulai produksi dari tahun 2011 produksi dari kacang kapri ini per harinya 10 kilogram. UMKM tidak berkenan dilakukan promosi karena takut akan permintaan konsumen yang banyak karena karyawan di UMKM tersebut terbatas. Selama masa pandemi ini tenaga kerja dikurangi dan diliburkan karena penurunan dari jumlah konsumen. Solusi yang dilakukan oleh pihak produksi tetap dilanjutkan tergantung pesanan, agar usaha kacang kapri (PIN 2) ini tetap berjalan. Pemilik berharap agar usaha tetap berjalan dan COVID-19 ini cepat berlalu.

Serupa dengan usaha kacang kapri PIN 2, di Dusun Bajing, Desa Tegak juga memiliki satu lagi UMKM usaha kacang kapri. Usaha yang dimiliki oleh Bapak Wayang Sumandiyasa dan dinamakan ABI-YAN ini mulai beroperasi pada bulan Mei 2018. Bapak Wayan bekerja sendiri, produksi kacang kapri $9 \mathrm{~kg}$ per 3 hari untuk pengambilan/pembelian bahan di pasar. Selama masa pandemi penjualan kacang kapri menurun hingga 50\%. Pada saat penjualan mengalami penurunan harga produksi bahan yang meningkat. Mahasiswa KKN-PPM-Pandemi Covid-19 turut membantu mempromosikan UMKM melalui platform media sosial. Pemilik berharap dengan bantuan promosi dari mahasiswa KKN dapat meningkatkan kembali profit dari usahanya dan membantu memperluas jaringan pelanggan di luar Desa Tegak dan juga bapak Wayan berharap agar usahanya tetap produksi dan usahanya tetap berjalan.

\section{Program Edukasi Cara Mencuci Tangan yang Benar}

Program kedua ini merupakan kegiatan praktik (langsung ke lapangan) bertempat di Sekolah TK B Satya Kumara Dewa, di Kantor Desa Tegak, Kecamatan Klungkung, Kabupaten Klungkung. Dalam kegiatan ini mahasiswa KKN mengadakan sosialisasi dan memberikan edukasi cara mencuci tangan yang benar kepada anak-anak sekolah TK B Satya Kumara Dewa Desa Tegak. Hasil dari program edukasi cara mencuci tangan, ditemukan permasalahan. Seperti yang sudah menjadi rahasia umum tangan merupakan salah satu anggota tubuh yang sering membawa dan menularkan kuman. Bahkan penyebaran Covid-19 ini juga salah satunya melalui tangan. Jika terkontaminasi penderitanya, tangan yang terkontaminasi akan menyentuh hidung, mata dan mulut. Sebagian besar anak-anak usia dini khususnya di TK B Satya Kumara Dewa, di Desa Tegak belum berperilaku benar dan sehat dalam mencuci tangan yang sesuai dengan standar kesehatan. Selain itu sekolah juga memakai sistem sekolah daring/online sehingga pihak sekolah pun belum pernah memberikan edukasi kembali terkait cara mencuci tangan dan pentingnya rajin mencuci untuk kesehatan. Sebagai pemecahan dari masalah tersebut, Mahasiswa KKN-PPM-Pandemi Covid-19 memberikan edukasi, memberikan contoh, memperagakan dan mengajak anak-anak untuk mempraktikkan langsung cara mencuci tangan dengan baik dan benar. Diharapkan setelah pelaksanaan dari program di atas adalah 76 terdapat perubahan perilaku di masyarakat, utamanya para siswa Taman Kanak-kanak (TK) dapat memahami tata cara, dan dapat mempraktikkan bagaimana cuci tangan yang baik dan benar.

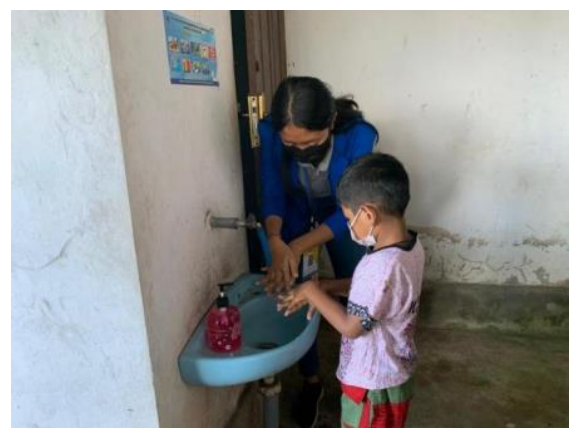

Gambar 2. Kegiatan Edukasi Cara Mencuci Tangan yang Benar 


\section{Program Pembagian Masker Gratis dan Pemasangan Poster Edukasi Pencegahan COVID-19}

Program ketiga dilakukan dengan membagikan membagikan masker gratis dan memasang poster edukasi pencegahan COVID-19. Program pembagian masker gratis merupakan kegiatan praktik (langsung ke lapangan) bertempat di Pasar Tegak, Kecamatan Klungkung, Kabupaten Klungkung. Dalam kegiatan ini mahasiswa KKN memberikan Masker gratis ke pedagang yang ada di pasar Tegak serta memberikan sosialisasi pentingnya penggunaan masker. Permasalahan yang ditemui berupa masih banyak warga tidak menggunakan masker saat beraktivitas. Sebagai pemecahan masalah, Mahasiswa KKN-PPM-Pandemi Covid-19 memberikan masker gratis. Diharapkan setelah pelaksanaan dari program di atas adalah masyarakat sekitar desa Tegak lebih peduli terhadap protokol kesehatan di masa pandemi COVID-19.

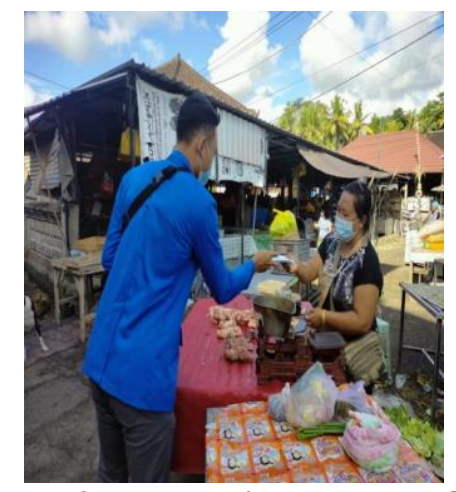

\section{Gambar 3. Pembagian Masker Gratis}

Selain pembagian masker gratis, dilakukan juga pemasangan poster. Masalah yang ditemukan adalah masih banyaknya warga yang tidak peduli dengan kesehatan serta penyebaran virus COVID-19. Pemecahan dari masalah tersebut yaitu mahasiswa KKN melakukan pemasangan poster untuk membuat masyarakat melek akan pandemi dan informasi seputarnya. Diharapkan setelah pelaksanaan dari program di atas adalah masyarakat sekitar desa Tegak lebih peduli terhadap protokol kesehatan dan pencegahan penyebaran virus Covid-19.

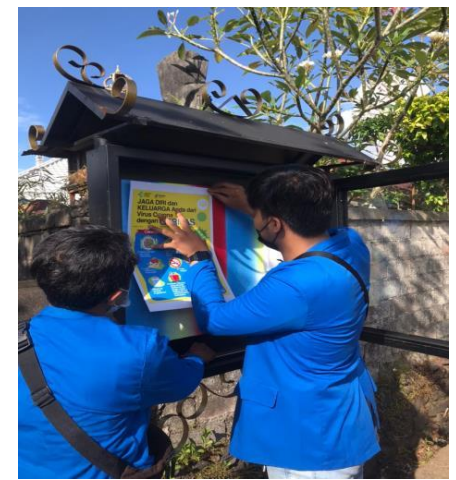

Gambar 4. Pemasangan Poster COVID-19

\section{Program Membantu Pelaksanaan Vaksinasi COVID-19}

Program keempat yang dilaksanakan adalah program membantu vaksinasi COVID-19 sebagai program yang mendukung agar Desa Tegak mampu bangkit dari pandemi. COVID-19 untuk warga yang ber-KTP Desa Tegak dengan jenis vaksin Astra Zeneca bertempat di Balai Wantilan Desa, Dusun Kaja Kangin, Desa Tegak. Dalam vaksinasi langsung di pantau oleh Wakil Bupati Klungkung, I Made Kasta bersama petugas dari Kecamatan Klungkung dan perangkat desa Tegak. Vaksinasi yang bertempat di Balai Wantilan Desa Tegak ini hanya dihadiri oleh 179 orang dari Kuota 260 orang. Ditemui permasalahan yaitu pada saat pemanggilan atau masyarakat yang hadir untuk vaksinasi secara bersamaan, sehingga menimbulkan kerumunan. Terlebih tempat atau lokasi vaksin tidak terlalu luas agar masyarakat tidak berkerumun dan Jumlah warga yang hadir masih rendah dibandingkan dengan kuota yang disediakan oleh pihak Dinas Kesehatan Kabupaten Klungkung, dimana dari kuota 
sebanyak 260 sedangkan yang hadir hanya 179 orang. Atau sebanyak 81 orang atau sebanyak 20 persen tidak hadir tanpa memberikan 87 keterangan. Untuk masalah tersebut, diselesaikan dengan cara mahasiswa KKN membantu memberikan pengarahan masyarakat agar mengantre sesuai nomor antrean yang sudah diberikan, dengan tidak berkerumun, tetap menjaga jarak dan datang ke lokasi vaksin saat dipanggil petugas. Imbauan Mahasiswa KKN dan kehadiran pejabat daerah cukup memberikan efek positif masyarakat bisa lebih menaati protokol kesehatan, untuk mencegah penularan virus COVID 19 dengan klaster-klaster baru. Mahasiswa KKN juga ikut memberikan pengarahan agar masyarakat tidak takut untuk di vaksin, sehingga semua sehat dan terhindar dari virus corona. Program kerja ini diharapkan mampu membantu memperlancar kegiatan vaksinasi dan memberikan pemahaman kepada warga Desa Tegak yang mendapatkan vaksin agar masyarakat tidak takut untuk di vaksin, karena vaksin dapat memberikan anti body pada tubuh sehingga tidak mudah terpapar oleh virus COVID - 19.

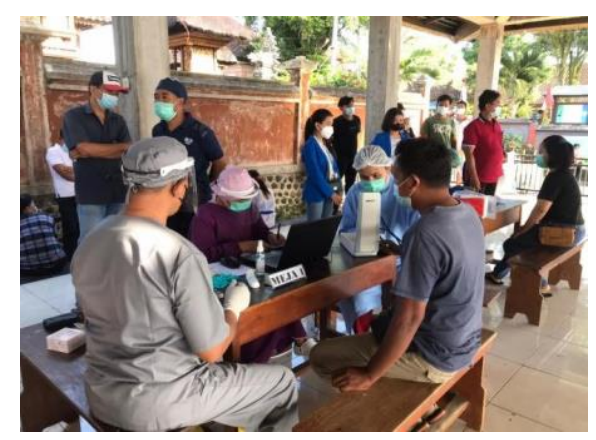

Gambar 5. Membantu Vaksinasi COVID-19

\section{Membantu Kegiatan Posyandu}

Program kelima yang dilaksanakan oleh mahasiswa KKN Universitas Warmadewa adalah program membantu kegiatan posyandu. Sejalan dengan tujuan membuat masyarakat sehat untuk melewati pandemi, kegiatan ini dilaksanakan oleh petugas puskesmas dan para kader Desa Tegak banjar Kaja Kangin dan dibantu oleh mahasiswa KKN. Kegiatan posyandu di lakukan di bale banjar banjar dinas Kaja Kangin kegiatan posyandu berupa Pendataan gizi balita, Pemberian Makanan Tambahan (PMT) kepada balita, melakukan pengukuran berat badan, tinggi badan, lingkar kepala. Dan lingkar tangan balita. Jumlah balita yang terdata sebanyak 35 orang, tetapi masih ada beberapa balita yang tidak datang ke poayandu karena kesibukan orang tua nya bahkan ada beberapa balita yang jarang sekali melakukan kegiatan posyandu. Di harapkan tetap mematuhi protocol kesehatan dan para kader desa atau petugas puskesmas memberikan informasi dengan menyeluruh kepada semua para orang tua balita agar selalu hadir dalam kegiatan posyandu. Diharapkan juga agar semua orang tua balita mengetahui perkembangan anaknya dengan baik supaya tidak ada balita yang mengalami gangguan pada pertumbuhannya.

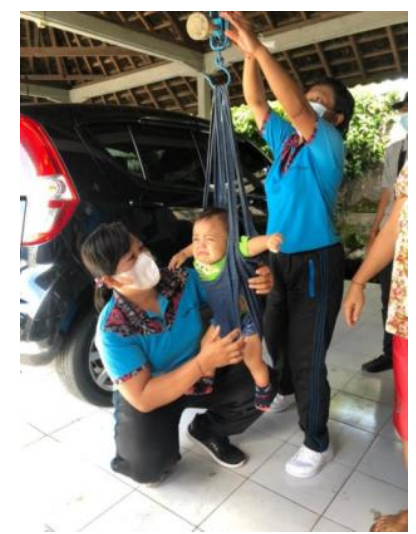

Gambar 6. Kegiatan Posyandu

Kegiatan Penyerahan Bantuan Langsung Tunai (BLT) Dana Desa Tegak Tahun Anggaran 2021 


\section{Tahap V Bulan Mei 2021}

Program keenam yaitu membantu kegiatan penyerahan BLT untuk warga Desa Tegak. Jumlah penerima BLT pada dusun kaja kangin sebanyak 41, dusun tengah sebanyak 41, dusun tulang nyuh sebanyak 21, dusun bajing sebanyak 7 . Permasalahan yang ditemui berupa masih banyak warga tidak menggunakan masker saat beraktivitas. Sebagai pemecahan masalah, mahasiswa KKN ikut membantu pihak desa agar penyerahan BLT tersebut berjalan lancar dengan mematuhi protokol kesehatan seperti cek suhu tubuh warga dan memakai hand sanitizer, dan juga mengatur warga agar antre dan menjaga jarak saat proses penyerahan BLT tersebut. Diharapkan kepada masyarakat agar tetap mematuhi protokol kesehatan.

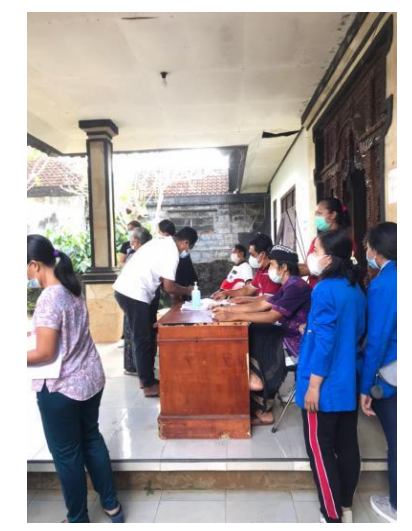

\section{Gambar 7. Membantu Penyerahan BLT}

\section{Program Survey Pendataan Penduduk SDGs Desa Tahun 2021}

Program ketujuh adalah survey pendataan penduduk SDGs Desa tahun 2021. Kegiatan ini merupakan kegiatan praktik langsung yang mana dalam 1 kelompok terdiri atas 6 orang mahasiswa dan didampingi oleh staf lembaga desa untuk melakukan pendataan ke rumah-rumah warga di Desa Tegak.Survey dilakukan di empat lokasi, yaitu di Dusun Tulang Nyuh, Dusun Tengah, Dusun Kaja Kangin, dan Dusun Bajing.

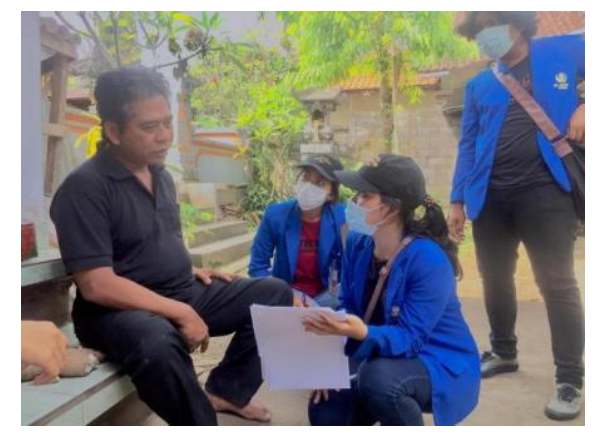

\section{Gambar 8. Survey dan Pendataan SDGs}

Untuk di Dusun Tulang Nyuh, permasalahan yang didapat saat kegiatan yaitu pada saat pelaksanaan survey kunjungan ke rumah warga, masih banyak warga yang tidak menerapkan protokol kesehatan seperti tidak memakai masker. Saat penginputan data penduduk SDGs, terbatasnya waktu pendataan menyebabkan kegiatan tidak berjalan optimal.Sebagai pemecahan masalah, mahasiswa KKN ikut membantu Tim Pokja Pendataan SDGs Desa Tegak dalam proses pendataan SDGs ini selalu menyarankan warga untuk menerapkan protokol kesehatan serta membantu penginputan data tersebut untuk mempercepat proses pendataan agar dapat selesai sesuai waktu yang ditentukan. Diharapkan setelah pelaksanaan dari program di atas adalah terselesaikannya pendata SDGs tempat sesuai dengan waktu yang telah di tentukan dan data dapat digunakan sebagaimana fungsinya. Dan kegiatan SDGs ini tetap dilakukan sehingga mengetahui kesejahteraan warga Desa Tegak. Partisipasi dari warga juga sangat dibutuhkan untuk melancarkan kegiatan ini.

Selanjutnya di Dusun Tengah, permasalahan yang ditemui serupa dengan di sebelumnya, yaitu kurangnya waktu dan kurangnya tenaga kerja untuk menginput data. Sebagai pemecahan masalah, 
Mahasiswa KKN ikut membantu Tim Pokja Pendataan SDGs Desa Tegak dalam proses pendataan SDGs ini mensurvey data Keluarga dan data Individu berkunjung ke rumah - rumah warga dengan menerapkan protokol kesehatan. Serta membantu penginputan data tersebut untuk mempercepat proses pendataan agar dapat selesai sesuai waktu yang ditentukan. Diharapkan setelah pelaksanaan dari program di atas adalah terselesaikannya pendata SDGs tempat sesuai dengan waktu yang telah di tentukan dan data dapat digunakan sebagaimana fungsinya. Dan kegiatan SDGs ini tetap dilakukan sehingga mengetahui kesejahteraan warga Desa Tegak. Partisipasi dari warga juga sangat dibutuhkan untuk melancarkan kegiatan ini.

Di Dusun Kaja Kangin, mahasiswa KKN menemui masalah yang berbeda, yaitu Ada beberapa warga yang sedang tidak ada di rumah sehingga belum bisa mendata di beberapa KK. Masih banyak masyarakat menggunakan Hp yang tidak berisi sosial media (WA, FB, Twitter, dll) sehingga banyak data yang dikosongkan. Sebagai pemecahan masalah, mahasiswa KKN memutuskan untuk mencari data di lain waktu saat warga ada di rumah dan mengosongkan data yang tidak dimiliki oleh warga. Diharapkan setelah pelaksanaan dari program di atas adalah terselesaikannya pendata SDGs tempat sesuai dengan waktu yang telah di tentukan dan data dapat digunakan sebagaimana fungsinya. Dan kegiatan SDGs ini tetap dilakukan sehingga mengetahui kesejahteraan warga Desa Tegak. Partisipasi dari warga juga sangat dibutuhkan untuk melancarkan kegiatan ini.

Terakhir, di Dusun Bajing, mahasiswa KKN menemukan masalah berupa ada beberapa warga yang sedang tidak ada di rumah sehingga belum bisa mendata di beberapa KK sehingga minim informasi data yang di peroleh. Sebagai pemecahan masalah, dipilih pencarian data di lain waktu saat warga ada di rumah dan menginformasikan ke kerabat terdekat warga yang tidak ada di rumah bahwa akan ada survey hari selanjutnya. Diharapkan setelah pelaksanaan dari program di atas adalah terselesaikannya pendata SDGs tempat sesuai dengan waktu yang telah di tentukan dan data dapat digunakan sebagaimana fungsinya. Dan kegiatan SDGs ini tetap dilakukan sehingga mengetahui kesejahteraan warga Desa Tegak. Partisipasi dari warga juga sangat dibutuhkan untuk melancarkan kegiatan ini.

\section{Program Peningkatan Sanitasi dan Peduli Lingkungan}

Setelah melaksanakan program sanitasi dan peduli lingkungan, terdapat beberapa hal yang patut dilaporkan terkait dengan metode pelaksanaan dan hal yang harus dievaluasi. Untuk kegiatan gotong royong, pertama, metode pelaksanaan dari program ini adalah dengan melakukan gotong royong di Sumber Air Tirta Sudamala Centeng. Sebelumnya gotong royong rutin dilaksanakan oleh masyarakat desa Tegak. Gotong royong pada program kerja KKN dilaksanakan dengan bantuan masyarakat Desa Tegak dan Mahasiswa KKN. Permasalahan di sini adalah kurangnya kesadaran masyarakat sekitar untuk menjaga kebersihan lingkungan di sekitar Sumber Air Tirta Sudamala Centeng. Sedangkan, untuk menyelesaikan masalah tersebut diusulkan kedepannya mengadakan gotong royong secara rutin yang jadwalnya dapat dibagi berdasarkan dusun yang ada di Desa Tegak, agar lingkungan di sekitar sumber air tetap bersih, sehingga dapat dikembangkan menjadi objek wisata Sumber Air Tirta Sudamala Centeng. Diharapkan juga program ini dapat memberikan kontribusi dan dapat berlanjut untuk terjaganya kebersihan Sumber Air Tirta Sudamala Centeng.

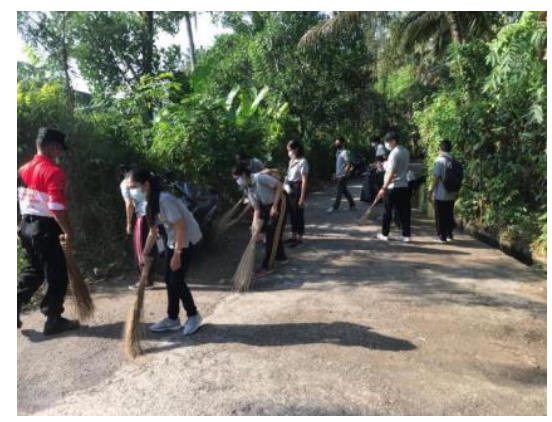

\section{Gambar 9. Gotong Royong Membersihkan Lingkungan}

Selain gotong royong, untuk meningkatkan sanitasi juga dilakukan program membantu kegiatan Opnam Purna Laksana dalam pengukuran MCK umum di Desa Tegak. Kegiatan ini dilakukan 
khususnya di Dusun Kaja Kangin dan Dusun Tulang Nyuh.Pemerintah Klungkung memberikan bantuan berupa pembangunan beberapa MCK/Jamban umum di Dusun Kaja Kangin dan Tulang Nyuh karena sebagian warga tidak memiliki jamban di rumahnya sehingga pemerintah memberikan bantuan tersebut. Pembangunan MCK/Jamban sudah berada pada tahap akhir atau purna laksana maka di perlukan kegiatan opnam guna memastikan apakah pembangunan tersebut sudah sesuai dengan arahan dari pemerintah. Permasalahan yang ditemui berupa pembangunan bantuan MCK/Jamban ukuran luas dan lebar bangunannya belum dapat di pastikan benar sesuai dengan ukuran yang di tentukan. Sebagai pemecahan masalah, mahasiswa KKN membantu proses pengukuran MCK/ Jamban sehingga dapat mengetahui sesuai atau tidak bantuan MCK/Jamban yang di berikan oleh pemerintah. Program kerja ini diharapkan mampu membantu memperlancar kegiatan opnam purna laksana pembangunan MCK/jamban dan bantuan yang di berikan oleh pemerintah dapat di gunakan oleh warga Dusun Kaja Kangin dan Tulang Nyuh dengan baik dan sesuai dengan fungsinya.

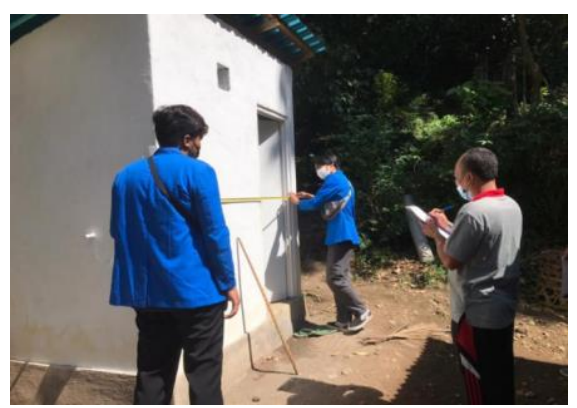

Gambar 10. Pengukuran Fasilitas MCK

\section{SIMPULAN}

Kesimpulan pelaksanaan kuliah kerja nyata (KKN) di Desa Tegak, kecamatan Klungkung, Kabupaten Klungkung berjalan dengan baik dan lancar. Program yang telah dilaksanakan sesuai dengan tema yang diberikan oleh pihak Universitas Warmadewa, yaitu Memperkuat Pembangunan Sosial Untuk Akselerasi Pembangunan Ekonomi Di masa Pandemi COVID-19. Dukungan masyarakat cukup tinggi dimana masyarakat menyambut baik kegiatan kami selama KKN dan tidak ada rasa kekhawatiran karena saat ini masih dalam kondisi pandemi COVID19.

\section{DAFTAR PUSTAKA}

Adhi, E. T. (2009). Pelayanan sanitasi buruk: Akar dari kemiskinan. Jurnal Analisis Sosial, 14(2), 7687.

Assri, B. C. A. (2020). Kebijakan Luar Negeri Amerika Serikat Terhadap Iran Selama Pandemi Covid-19. Jurnal ICMES, 4(1), 29-45.

Floridiana, Z. (2019). Analisis Higiene Penjamah Makanan dan Sanitasi Lingkungan pada Industri Rumah Tangga Tahu Jombang 2018. Jurnal Kesehatan Lingkungan, 11(1), 75-82.

Hanoatubun, S. (2020). Dampak Covid - 19 terhadap Prekonomian Indonesia. EduPsyCouns: Journal of Education, Psychology and Counseling, 2(1), 146-153.

Moleong. (2010). Metodologi Penelitian Kualitatif. Bandung: PT Remaja Rosdakarya. 